Dermatology 2016;232:520

DOI: $10.1159 / 000448215$

\section{Reply to Lipsker et al. and Revuz on Hidradenitis Suppurativa Terminology: The Imaging Point of View}

\section{Ximena Wortsman}

Departments of Radiology and Dermatology, Institute for Diagnostic Imaging and Research of the Skin and Soft Tissues, Clinica Servet, Faculty of Medicine, University of Chile, Santiago, Chile

\section{Key Words \\ Hidradenitis suppurativa $\cdot$ Terminology $\cdot$ Imaging}

I read with great interest the articles published by Lipsker et al. $[1,2]$ and Revuz [3] on hidradenitis suppurativa (HS) terminology. Indeed, it is valuable to have a common clinical terminology for HS. This can provide a tool for supporting the reproducibility of the outcomes, both in the clinical and research areas.

However, the clinical concepts of nodule, sinus, fistula or tunnel may be limited due to the lack of anatomical information on the deep part of these 3-dimensional structures. Moreover, these abnormalities present coordinates of spatial location that may not necessarily fit with the information provided by palpation.

On imaging, the definition of a nodule is volumetric and implies a usually round or oval-shaped structure with a different pattern of density from the surrounding tissue at all its borders. Size can be a matter for discussion but is commonly around $0.5-1 \mathrm{~cm}$. This concept has been used for defining and monitoring lung or thyroid nodules for example on computed tomography and ultrasound [4-7].

Thus, the clinical dermatological description of a nodule may be more similar to a lump or bump. In our experience, working on ultrasound imaging, we actually do not see well-defined nodules when we study clinically named nodules in HS patients. Usually, these clinical nodules correspond to fluid collections or fistulous tracts with or without inflammatory signs (increased vascularity). The drainage openings are usually connected to fluid collections or fistulous tracts running underneath sometimes apparently normal skin in the vicinity. The cords frequently correspond to fistulous tracts with prominent fibrotic scarring; nevertheless, not all the palpable cords exactly match fistulae, and some of them can be just scarring. Besides that, there are nonpalpable fistulous tracts, hidden to the clinical examination, that run through the dermis and hypodermis sometimes for several centimeters, which do not open to the surface and just connect to the widened base of regional hair follicles or to other fistulous tracts.
Furthermore, the latter experience has been reported by researchers working in different countries $[8,9]$.

Therefore, considering the information and definitions of key subclinical anatomical lesions (pseudocyst, fluid collection, fistulous tract) in HS that have been described by imaging, particularly color Doppler ultrasound in the adult and pediatric population [8, 10], the initial clinical discordance between experts reported by Lipsker et al. [1] is not surprising. Moreover, the difficulty of achieving common definitions on just clinically based examinations or staging systems that could match the actual anatomical abnormalities with their exact spatial positioning and volumetric features is also to be expected.

Therefore, from the imaging point of view, the usage of an anatomically based common terminology in HS that could bring together the experience of a multispecialist team with clinicians, imaging professionals and pathologists may perhaps simplify the task in the future.

\section{Disclosure Statement}

The author has no conflicts of interest to disclose.

\section{References}

1 Lipsker D, Severac F, Freysz M, Sauleau E, Boer J, Emtestam L, Matusiak Ł, Prens E, Velter C, Lenormand C, Meyer N, Jemec GB: The ABC of hidradenitis suppurativa: a validated glossary on how to name lesions. Dermatology 2016;232:137-142.

2 Lipsker D: Reply to Revuz' letter entitled 'Hidradenitis suppurativa: terminology'. Dermatology 2016;232:382.

-3 Revuz J: Hidradenitis suppurativa: terminology. Dermatology 2016;232: 381.

4 Young S, Kim HJ, Ko MM, Ko WW, Flores C, McNitt-Gray MF: Variability in CT lung-nodule volumetry: effects of dose reduction and reconstruction methods. Med Phys 2015;42:2679-2689.

5 Chen B, Barnhart H, Richard S, Robins M, Colsher J, Samei E: Volumetric quantification of lung nodules in $\mathrm{CT}$ with iterative reconstruction (ASiR and MBIR). Med Phys 2013;40:111902.

-6 Paschke R, Hegedüs L, Alexander E, Valcavi R, Papini E, Gharib H: Thyroid nodule guidelines: agreement, disagreement and need for future research. Nat Rev Endocrinol 2011;7:354-361.

7 Li Z, Franklin J, Zelcer S, Sexton T, Husein M: Ultrasound surveillance for thyroid malignancies in survivors of childhood cancer following radiotherapy: a single institutional experience. Thyroid 2014;24:17961805.

8 Wortsman X, Moreno C, Soto R, Arellano J, Pezo C, Wortsman J: Ultrasound in-depth characterization and staging of hidradenitis suppurativa. Dermatol Surg 2013;39:1835-1842.

-9 Martorell A, Segura Palacios JM: Ultrasound examination of hidradenitis suppurativa. Actas Dermosifiliogr 2015;106(suppl 1):49-59.

10 Wortsman X, Rodriguez C, Lobos C, Eguiguren G, Molina MT: Ultrasound diagnosis and staging in pediatric hidradenitis suppurativa. Pediatr Dermatol 2016;33:e260-264.

\section{KARGER}

E-Mail karger@karger.com

www.karger.com/drm (c) 2016 S. Karger AG, Base

$1018-8665 / 16 / 2324-0520 \$ 39.50 / 0$
Ximena Wortsman, MD, Departments of Radiology and Dermatology Institute for Diagnostic Imaging and Research of the Skin and Soft Tissues Clinica Servet, Faculty of Medicine, University of Chile Lo Fontecilla 201, Of 734, Las Condes, Santiago (Chile)

E-Mail xworts@yahoo.com 